\title{
RANCANG BANGUN SISTEM INFORMASI BANTUAN LOGISTIK BENCANA STUDI KASUS PADA BPBD KABUPATEN MAGELANG
}

\author{
Dyah Ika Rinawati ${ }^{1}$, Diana Puspita Sari ${ }^{1}$, Fuzie Priatamphatie ${ }^{1}$, Fahrudin $^{2}$ \\ ${ }^{1}$ Departemen Teknik Industri, Fakultas Teknik, Universitas Diponegoro \\ ${ }^{2}$ Departemen Teknik Geologi, Fakultas Teknik, Universitas Diponegoro \\ Jl. Prof. H. Soedarto, SH, Kampus Undip Tembalang, Semarang, Indonesia 50275
}

(Received: December 5, 2017/Accepted: January 8, 2018)

\begin{abstract}
Abstrak
Pada kegiatan distribusi bantuan logistik untuk korban bencana alam, terdapat beberapa permasalahan antara lain penumpukan barang bantuan di titik tertentu namun terjadi kekurangan pada titik lain atau sebaliknya bantuan yang diberikan terlalu banyak dan kurang bermanfaat. Permasalahan tersebut disebabkan kurangnya informasi mengenai data korban bencana, data jenis bantuan yang diperlukan dan data bantuan yang telah tersedia. Guna mewujudkan efisiensi dan efektivitas dalam distribusi logistik bantuan bencana diperlukan sistem informasi yang dapat mendukung distribusi bantuan logistik secara tepat waktu, tepat lokasi, tepat kuantitas dan sesuai kebutuhan. Perancangan sistem informasi ini meliputi pengumpulan data, analisis sistem, desain sistem, implementasi dan analisis terhadap hasil pengujian. Penelitian ini dilakukan pada BPPD Kabupaten Magelang, dimana proses manajemen bantuan logistik yang dilakukan terdiri dari fase perencanaan dan fase penerimaan atau pengadaan bantuan. Sistem informasi yang telah dibangun dapat mempercepat perhitungan jenis dan jumlah komoditi yang dibutuhkan. Selain itu, dengan adanya sistem informasi ini, pencatatan penerimaan bantuan dapat disinkronisasi sehingga seluruh komoditi yang telah tersedia di masing-masing lokasi dapat diketahui. Output sistem informasi ini dapat dipublikasikan secara luas kepada masyarakat, sehingga respon penanggulangan terhadap bencana akan lebih cepat dan efektif.
\end{abstract}

Kata Kunci: Sistem Informasi; Manajemen Bantuan Bencana; Bencana Alam

\begin{abstract}
Information System Development for Disaster Relief Logistics - Case Study in BPPD Magelang District. In the disaster relief logistics distribution, there are some problems such as the excess of goods aid at a certain point but there is a shortage at another point or overamount of goods aid that being not useful. The problem is due to lack of information about the data of disaster victims, data of the type and amount of humanitarian aid needed and goods aid that already provided. In order to realize efficiency and effectiveness in the distribution of disaster relief logistics, an information system that can support the distribution of relief disaster logistics by on time, precise location and precise quantity is needed. This information system development consist of data collection, system analysis, system design, implementation and analysis of test results. This research was conducted at BPPD of Magelang District, where the logistic aid management process consisted of planning and receiving phase or procurement phase. Information systems that have been built are able to accelerate the calculation of the type and number of goods aid. In addition, with this information system, recording of aid receipts can be synchronized so that all goodes aid that have been available in each locations can be known. The output of this information system can be widely published, so that the disaster responses will be faster and more effective.
\end{abstract}

Keywords: Information System; Relief Disaster Logistic; Disaster

\footnotetext{
${ }^{*}$ Penulis Korespondensi. email: dyah.ika@gmail.com
} 


\section{PENDAHULUAN}

Bencana adalah istilah yang mengacu pada gangguan yang secara fisik mempengaruhi sistem secara keseluruhan dan mengancam prioritas dan tujuan (Cozzolino, 2012). Bencana didefinisikan sebagai peristiwa yang tak terduga dan seringkali terjadi secara tiba-tiba yang menyebabkan kerusakan besar, kehancuran, dan penderitaan manusia. Bencana dapat dibedakan dalam dua kategori umum, yaitu yang diakibatkan oleh alam dan buatan manusia atau teknologi. Bencana alam diklasifikasikan menjadi 12 jenis bencana, yaitu bencana gempa bumi, gunung api, mass movement (dry), mass movement (wet), banjir, badai, epidemis, infeksi serangga, serangan hewan, suhu ekstrim, kekeringan, dan kebakaran. Bencana alam yang termasuk dalam klasifikasi serangan mendadak (sudden onset) meliputi gempa, tsunami, erupsi gunung api, mass movement, banjir, dan badai sedangkan yang termasuk serangan lambat (slow onset) antara lain epidermis, kekeringan, dan suhu ekstrim.

Bencana alam berdampak pada kelangsungan hidup manusia. Oleh karena itu harus dilakukan upaya penanggulangan untuk meminimalkan dampak yang ditimbulkan. Upaya tanggap bencana dianggap sangat tidak pasti dan kompleks, maka harus dikelola dengan baik agar didapat respon yang lebih cepat. Indonesia telah mengatur pengelolaan penanggulangan bencana melalui UU No. 24 tahun 2007. Apapun jenis bencana yang terjadi, menurut O' Brien, dkk., (2010) tahapan dalam penanggulangan bencana tetap sama, pada umumnya terdiri atas 4 tahap yaitu mitigasi (mitigation), persiapan (preparedness), tanggapan (response), dan pemulihan (recovery). Karakteristik logistik penanggulangan bencana tentunya berbeda dengan karakteristik logistik komersial pada umumnya, salah satu karakteristiknya adalah bahwa tujuan utama dari aktivitas logistik penanggulangan bencana adalah meringankan penderitaan para korban bencana.

Berdasarkan UU nomor 24 tahun 2007 pasal 26 ayat 2 mengenai penanggulangan bencana menyatakan bahwa setiap orang yang menjadi korban bencana berhak mendapatkan bantuan dalam pemenuhan kebutuhan dasar. Dan menurut peraturan pemerintah Republik Indonesia nomor 22 tahun 2008 tentang pendanaan dan pengelolaan bantuan bencana pasal 28 ayat 1 bahwa bantuan pemenuhan kebutuhan dasar sebagaiaman dimaksud dalam pasal 24 ayat 2, diberikan kepada korban bencana dalam bentuk penampungan sementara, bantuan pangan, sandang, air bersih, sanitasi, dan pelayanan kesehatan. Pemerintah pusat dan daerah berkewajiban memberikan bantuan untuk meringankan penderitaan korban bencana. Bantuan dapat dihimpun dan dikerahkan dari dana APBN, APBD, bantuan dunia usaha, bantuan dari masyarakat di dalam negeri maupun luar negeri.
Dalam aktivitas distribusi bantuan kepada korban bencana alam selama masa tanggap darurat, lembagalembaga kemanusian, relawan, dan para donatur mengalami berbagai macam permasalahan di antaranya adalah kurang meratanya bantuan yang diberikan pada setiap posko, penumpukkan bantuan di titik tertentu namun terjadi kekurangan bantuan di titik lain, terjadi kekurangan pada komoditi tertentu atau sebaliknya bantuan yang diberikan terlalu banyak, dan kurang bermanfaat. Adanya permasalahan di atas disebabkan oleh kurangnya informasi mengenai data korban bencana, data bantuan yang telah diberikan, dan informasi mengenai donatur yang memberikan bantuan. Berdasarkan penelitian terdahulu yang dilakukan Oktarina (2008) menghasilkan pemetaan sistem informasi manajemen logistik dalam penanggulangan bencana di Indonesia. Hasil pemetaan menjadi dasar untuk merancang sistem informasi logistik penanggulangan bencana yang diharapkan dapat mengkoodinir semua pelaku dalam aktivitas logistik dan distribusi barang bantuan penanggulangan bencana. Selanjutnya Oktarina (2009) melakukan penelitian mengenai sistem informasi logistic (SI-Log) dengan pendekatan terpadu dalam mengelola barang bantuan penanggulangan bencana yang menitikberatkan pada pemetaan dan identifikasi pengorganisasian dan SI-Log. Nugraha dan Halim (2012) meneliti model penentuan lokasi barang pengungsian dan gudang pemasok dalam penanggulangan bencana alam mengasilkan output yaitu sebuah model penentuan lokasi barak pengungsian dan gudang pemasok yang optimal di kawasan rawan bencana merapi. Azlia (2010) penelitian ini mengembangkan, model untuk menentukan lokasi fasilitas gudang kesiapsiagaan untuk persiapan mengadapi bencana alam dengan mempertimbangkan kerentanan suatu wilayah. Guna mewujudkan efisiensi dan efektivitas dalam distribusi logistik bantuan bencana diperlukan sistem informasi yang dapat mendukung bantuan logistik secara tepat waktu, tepat lokasi, tepat kuantitas, dan sesuai kebutuhan.

\section{METODE PENELITIAN}

Metode penelitian ini menggunakan system development life cycle (SDLC). Menurut Whitten dan Bentley (2007), SDLC merupakan sekumpulan aktivitas, metode dan peralatan yang dibutuhkan oleh stakeholder sistem dalam membangun dan memelihara sistem. Adapun tahapan dari SDLC diuraikan sebagai berikut.

\section{a. Perencanaan (Identifikasi kebutuhan sistem) \\ Identifikasi kebutuhan sistem dilakukan berdasarkan wawancara kepada BPBD kabupaten Magelang dan 8 kepala desa di Kecamatan Srumbung Kabupaten Magelang. Data yang dibutuhkan adalah data desa yang berada di wilayah kecamatan Srumbung Kabupaten Magelang dan desa}


penyangganya, data jumlah penduduk berdasarkan rentang usia dan jenis kelamin, data kebutuhan logistik pada masa tanggap bencana berdasarkan peraturan kepala badan penanggulangan bencana (PERKA BNPB) nomor 18 tahun 2009 dan nomor 10 tahun 2012 mengenai pengelolaan bantuan logistik pada status keadaan darurat bencana.

\section{b. Analisis Sistem}

Pada tahap ini dilakukan analisis pengguna dan analisis sistem kebutuhan fungsional sistem informasi manajemen logistik bantuan. Analisis kebutuhan fungsional merupakan layanan yang harus diberikan atau disediakan oleh sistem.

\section{c. Desain Sistem}

Desain sistem terdiri dari 3 tahapan yaitu pemodelan proses, pemodelan data, dan desain antar muka. Tujuan akhir dari desain sistem ini adalah menghasilkan rancangan yang memenuhi kebutuhan yang ditentukan. Pemodelan proses adalah cara formal untuk untuk menggambarkan bagaiamana suatu sistem beroperasi. Pada penelitian ini digunakan diagram konteks, Data Flow Diagram dan Entity Relationship Diagram (ERD). Sedangkan pemodelan data dilakukan dengan perancangan struktur basis data. Tujuan dilakukan tahap ini adalah agar desain database sesuai dengan kebutuhan pada saat perancangan sistem. Database yang akan digunakan di dalam sistem informasi yang akan dibangun adalah MySQL. Desain antarmuka (interface) meliputi struktur menu, perancangan input, dan perancangan output meliputi frekuensi laporan, sisi laporan, bentuk laporan, dan laporan yang ditampilkan pada layar atau perlu dicetak.

\section{d. Implementasi}

Di dalam tahap implementasi terdiri dari 3 tahap yaitu penjadwalan, konstruksi sistem, dan pengujian.

\section{HASIL DAN PEMBAHASAN}

Pelaksanaan pengelolaan bantuan logistik bencana dalam status keadaan darurat terdiri dari fase perencanaan kebutuhan, fase penerimaan atau pengadaan bantuan, fase penyimpanan, fase pendistribusian, fase pengangkutan, fase penghapusan. Penelitian ini fokus untuk mengembangkan sistem informasi pada fase perencanaan, fase penerimaan barang bantuan yang termasuk dalam kategori logistik.

\section{Evaluasi Sistem yang Sedang Berjalan}

Sistem Pengelolaan Bantuan Logistik yang dilakukan oleh BPBD masih bersifat manual. Pada sistem yang berjalan saat ini masih terdapat beberapa kekurangan yaitu:

a. Tidak adanya informasi mengenai bantuan yang dibutuhkan oleh masing-masing posko desa.

b. Sehingga para donatur mengalami kesulitan untuk menentukan bantuan yang tepat bagi korban bencana alam.

c. Terjadi ketidakmerataan jumlah bantuan yang diberikan oleh para donatur dikarenakan tidak adannya informasi mengenai jumlah bantuan yang terdapat di setiap posko dan bantuan yang dibutuhkan setiap posko.

d. Posko Induk (BPBD) mengalami kesulitan untuk melakukan fungsi pengawasan terhadap pendistribusian, persediaan bantuan dikarenakan pencatatan bantuan yang masih manual.

e. Terjadi kekurangan bantuan yang diberikan dikarenakan tidak adanya informasi mengenai jumlah pengungsi yang ada di setiap posko desa.

\section{Analisis Pengguna}

Dalam sistem informasi dibutuhkan perancangan suatu sistem pengguna yang memberikan gambaran hakhak yang dimiliki oleh para pengguna sistem informasi tersebut. Secara umum ada empat (4) grup pengguna yaitu admin, petugas posko induk (posko BPBD), petugas posko desa, dan masyarakat pengunjung web sistem informasi logistik bencana. 


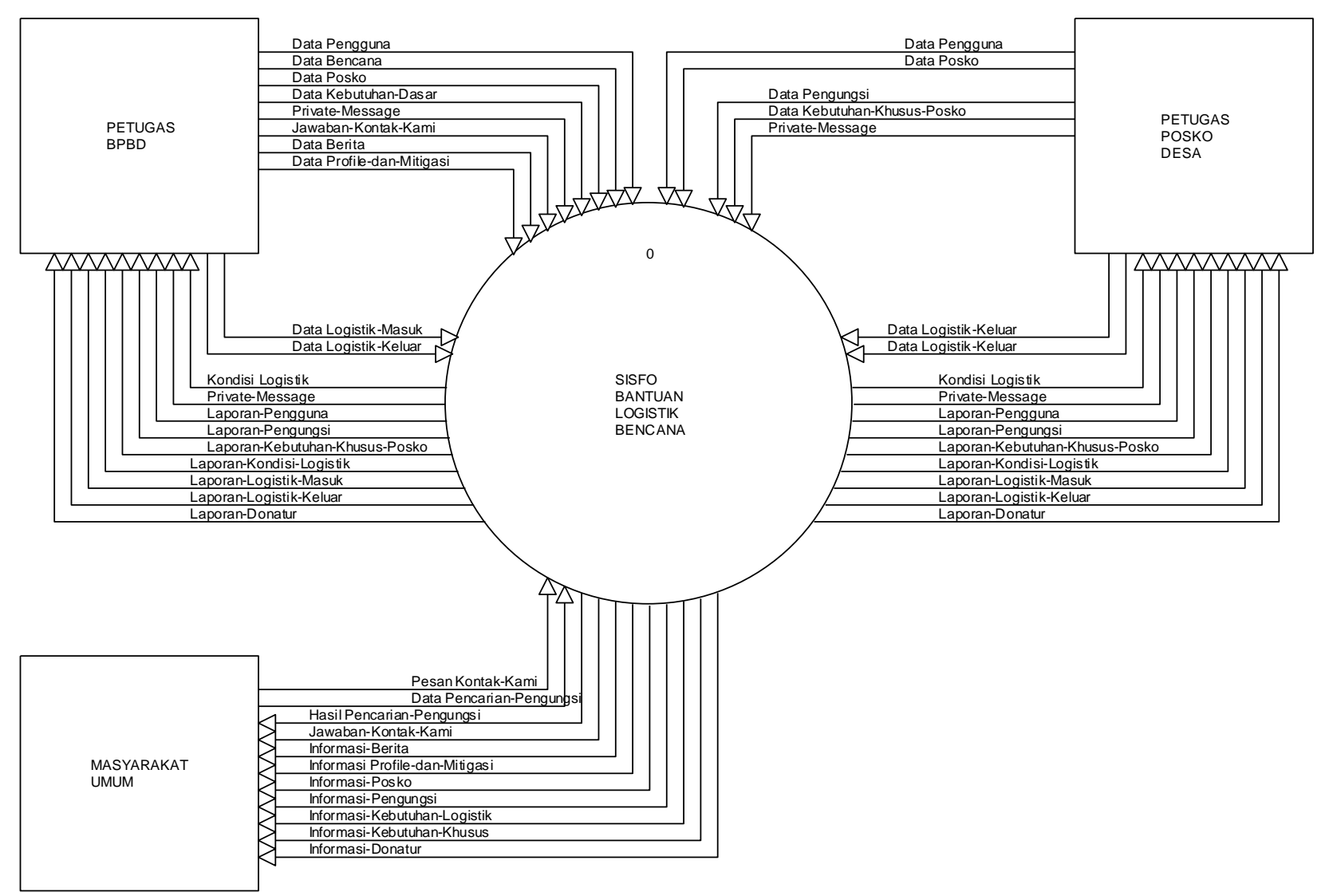

Gambar 1. Diagram Konteks

\section{Desain Proses}

a. Diagram konteks

Diagram konteks sistem informasi logistik bantuan bencana ditunjukkan pada Gambar 1. Pada sistem informasi bantuan logistik bencana terdapat 3 entitas yaitu petugas BPBD (petugas posko induk), petugas posko desa, dan pengunjung web sistem informasi bantuan logistik bencana (masyarakat umum). Petugas BPBD memiliki peran dalam mengolah data bencana, data pengguna, data kebutuhan dasar sebelum proses pengelolaan logistik bencana dilakukan. Petugas posko desa adalah petugas yang bertanggung jawab terhadap posko bencana di desa yang memiliki peranan dalam memasukkan data pengungsi, data kebutuhan khusus posko. Masyarakat umum adalah entitas luar yang memperoleh informasi posko, kebutuhan posko, daftar pengungsi, dan daftar donatur. b. Data Flow Diagram (DFD)

Data Flow Diagram (DFD) merupakan model dari sistem yang menggambarkan pembagian sistem ke modul yang lebih kecil. Terdapat tiga proses utama di dalam sistem yaitu pengaturan awal, mengelola logistik, dan menghasilkan informasi dan laporan. DFD level 1 sistem informasi bantuan logistik bencana ditunjukkan pada Gambar 2.

\section{c. Entity Relationship Diagram (ERD)}

Entity Relationship Diagram (ERD) digunakan untuk memodelkan secara konseptual hubungan antara entitas yang terjadi di dalam sistem informasi. Entitas yang terlibat serta relasi yang muncul disini selanjutnya akan dipakai dalam merancang kebutuhan database yang diperlukan. Gambar 3. merupakan ERD pada sistem informasi bantuan logistik bencana. 


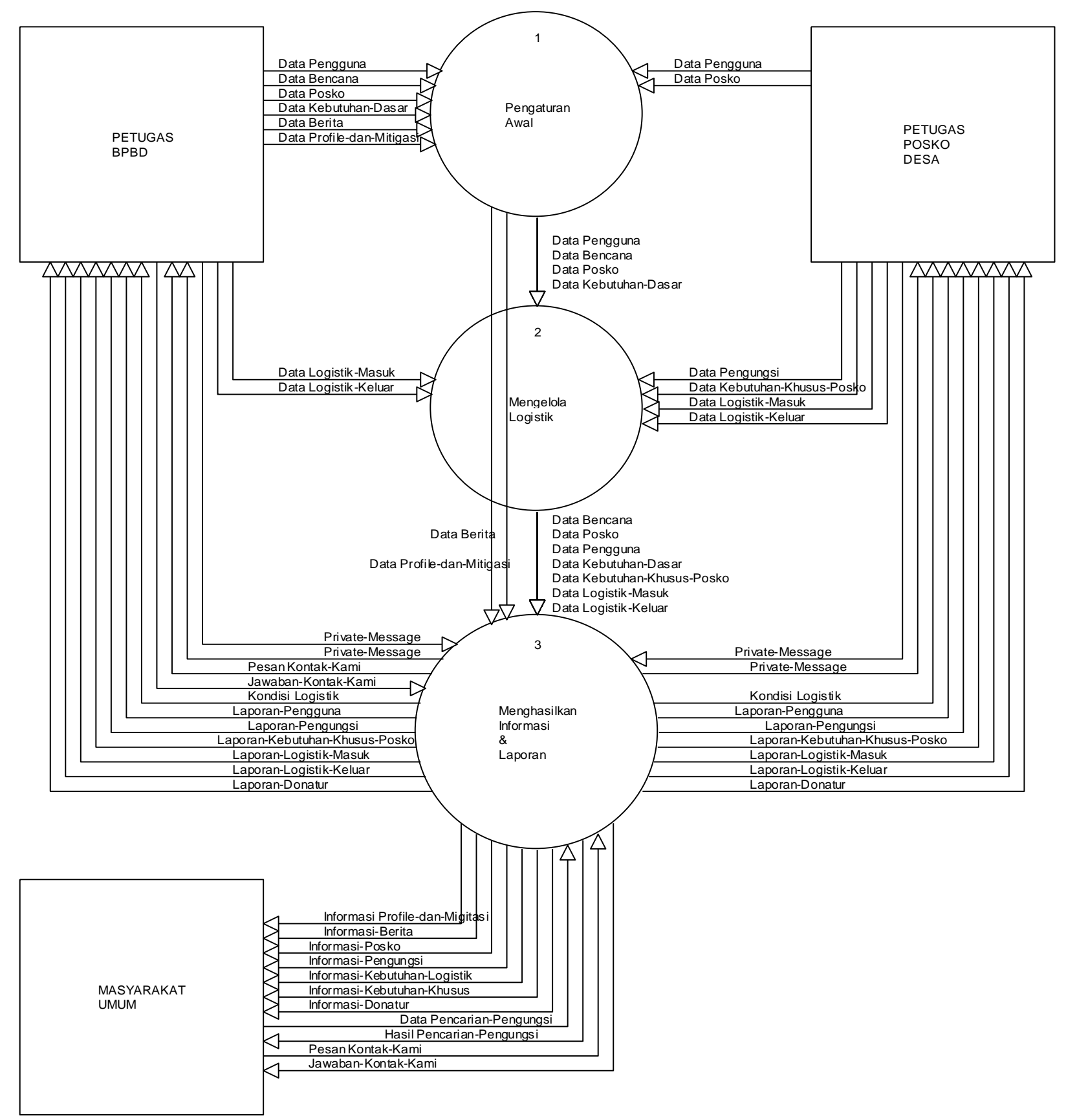

Gambar 2. DFD Level 1

\section{Desain Antarmuka (Interface)}

Berdasarkan identifikasi kebutuhan proses dan kebutuhan data yang telah dilakukan, maka selanjutnya adalah melakukan desain tampilan (interface) program yang akan dibuat.

\section{Implementasi}

Beberapa contoh implementasi dari sistem informasi bantuan logistik bencana (SIBALOGBEN) terdapat pada Gambar 4. sampai dengan Gambar 10.
1. Halaman utama SIBALOGBEN

Pada Gambar 4. ditunjukkan halaman beranda dengan beberapa menu yang dapat diakses yaitu menu pengungsi yang berfungsi untuk melihat data pengungsi, menu kebutuhan yang berisi standar kebutuhan logistik bantuan yang telah di atur oleh petugas posko induk BPBD, dan juga pada menu kebutuhan terdapat kondisi logistik posko induk BPBD dan juga kondisi logistik pada posko desa. 


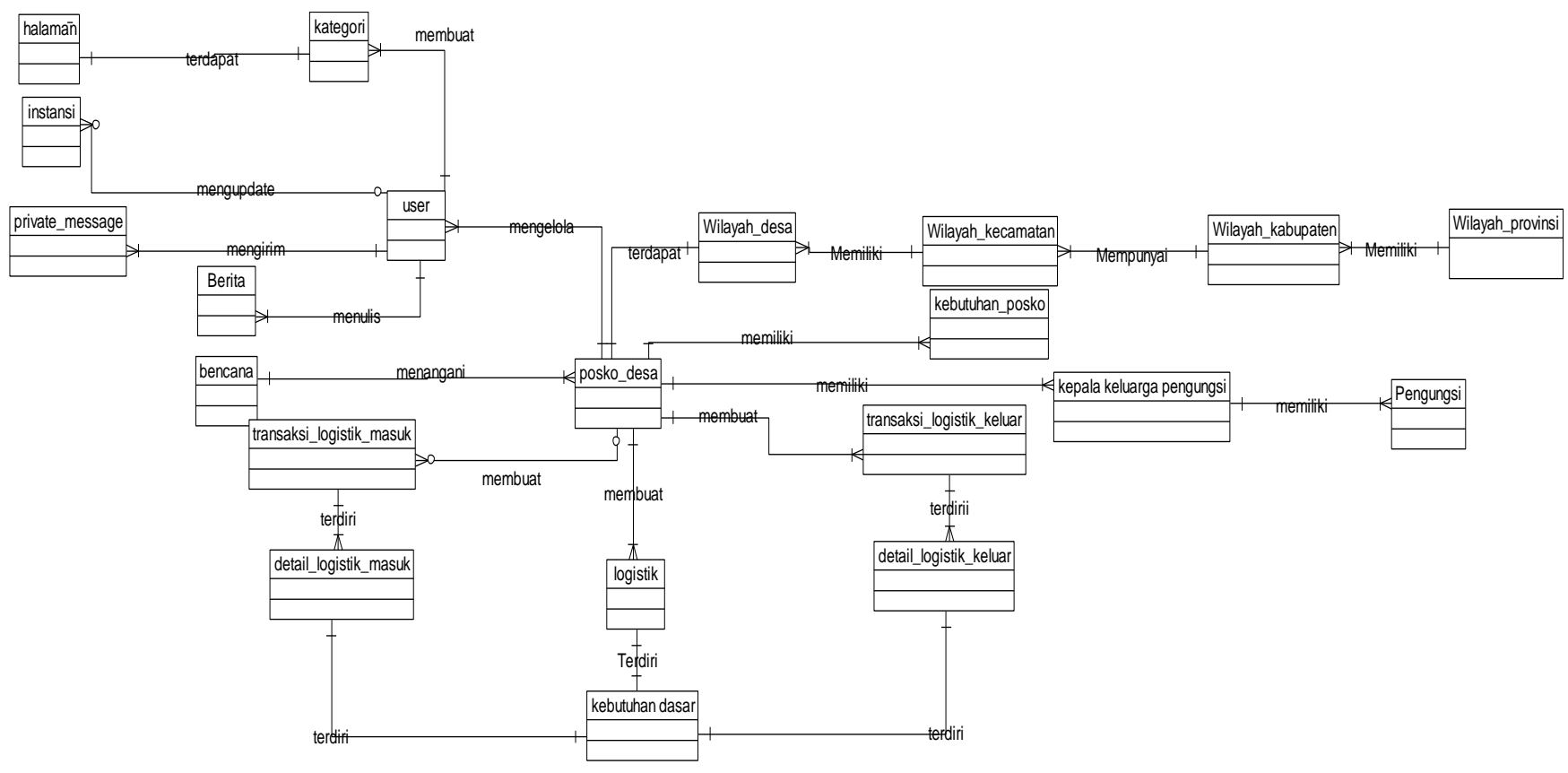

Gambar 3. Gambar ERD

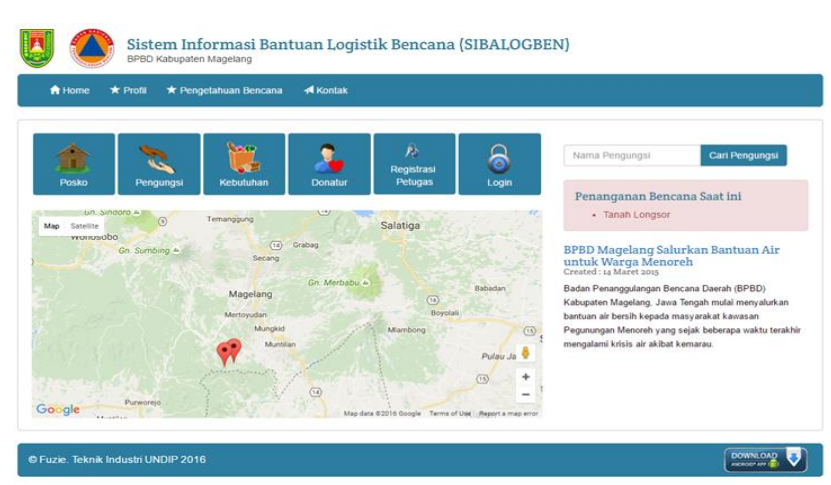

Gambar 4. Halaman Utama

Menu registrasi hanya dapat digunakan untuk membuat akun petugas posko desa. Akun tersebut baru bisa digunakan jika telah diaktifkan oleh petugas posko induk BPBD. Menu login berfungsi untuk sebagai "pintu" bagi akun petugas posko induk BPBD maupun petugas posko desa yang telah memiliki akun untuk masuk ke dalam sistem SIBALOGBEN.

Pada halaman beranda SIBALOGBEN terdapat menu yang digunakan untuk mengetahui keberadaan pengungsi melalui menu cari pengungsi. Peta Google Maps berfungsi untuk menggambarkan titik-titik posko penanganan

2. Halaman utama akun posko BPBD

Pada Gambar 5. merupakan halaman beranda petugas posko induk BPBD yang menampilkan menu kelola pengguna, kelola informasi, manajemen logistik, dan kontak kami. Dalam menu kelola pengguna petugas posko induk BPBD dapat mengelola akun pengguna petugas posko desa, dimana petugas posko induk BPBD bertugas untuk mengaktifkan dan menonaktifkan akun pengguna posko desa. Menu kelola informasi terdiri dari beberapa sub menu yaitu profil instansi, berita, kategori halaman, dan halaman.

Menu kelola informasi berfungsi untuk memberikan informasi kepada masyarakat pengunjung web. Pada menu manajemen logistik berfungsi terdiri dari beberapa sub menu yaitu kelola bencana dan posko, kelola kebutuhan dasar, transaksi logistik masuk dan keluar, melihat kondisi logistik dan melihat laporan. Pada menu kontak kami berfungsi untuk membalas semua pesan dari masyarakat pengunjung web yang mengirim pesan melalui menu kontak kami pada halaman utama. 


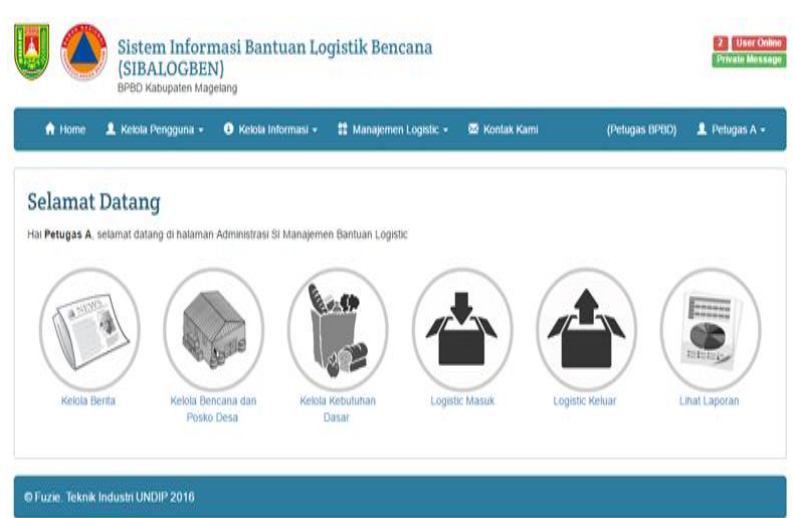

Gambar 5. Beranda akun posko BPBD

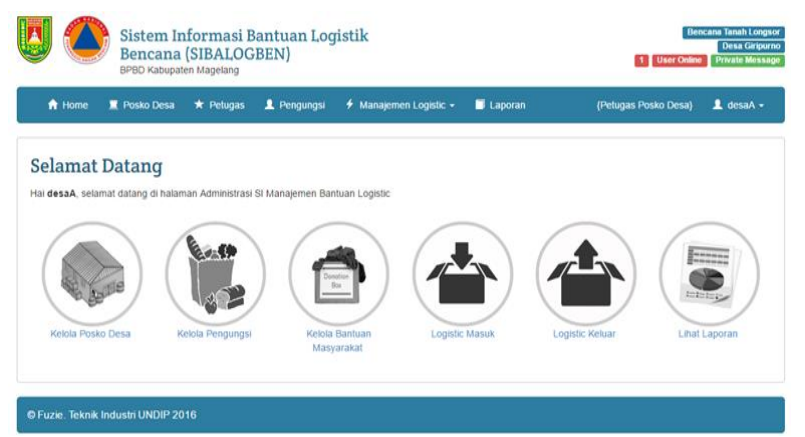

Gambar 6. Halaman Utama Akun Posko Desa
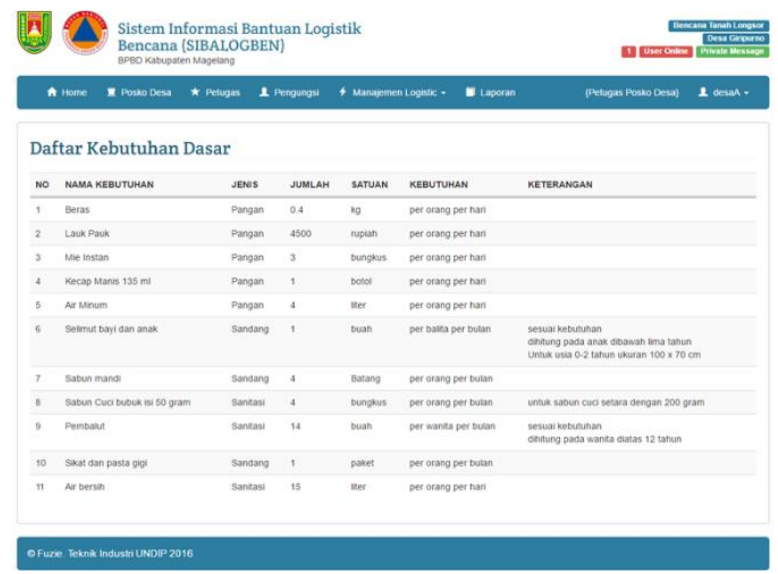

Gambar 7. Standar kebutuhan Logistik

3. Halaman utama akun posko desa

Gambar 6. merupakan gambar halaman beranda akun petugas posko desa. Pada akun ini terdapat informasi di pojok kanan atas yaitu bencana yang sedang ditangani, nama posko desa, jumlah pengguna dalam jaringan. Pada Gambar 6. juga terdapat menu menu diantaranya adalah menu kelola posko desa merupakan menu yang berfungsi untuk mengisi profil posko desa, menu kelola petugas posko desa digunakan untuk menambahkan, menyunting atau menghapus akun pengguna posko desa, menu kelola pengungsi berfungsi untuk memasukkan data diri pengungsi yang akan digunakan sebagai data perhitungan logistik. Menu manajemen logistik memiliki beberapa sub menu yaitu standar kebutuhan, kondisi logistik desa, transaksi logistik masuk dan keluar yang diterima oleh posko desa dan menu terakhir adalah menu mencetak laporan dalam bentuk file pdf. 


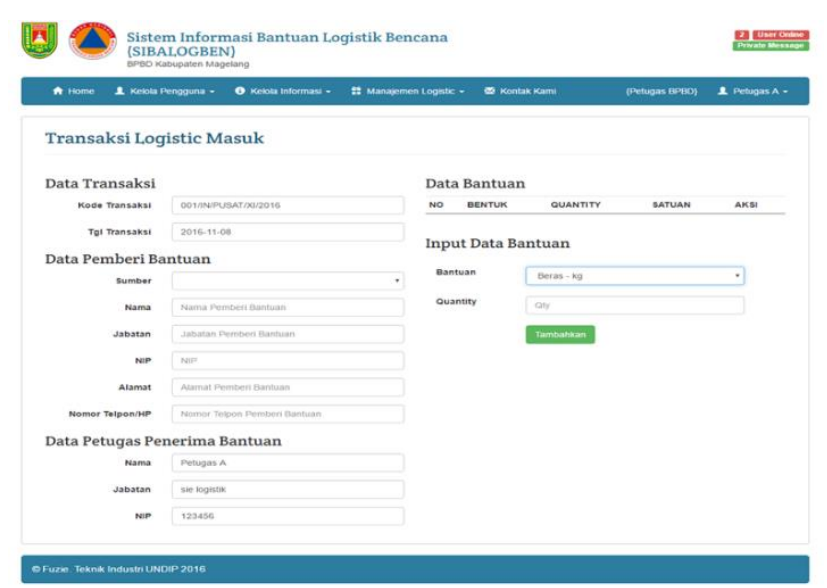

Gambar 8. Form logistik masuk

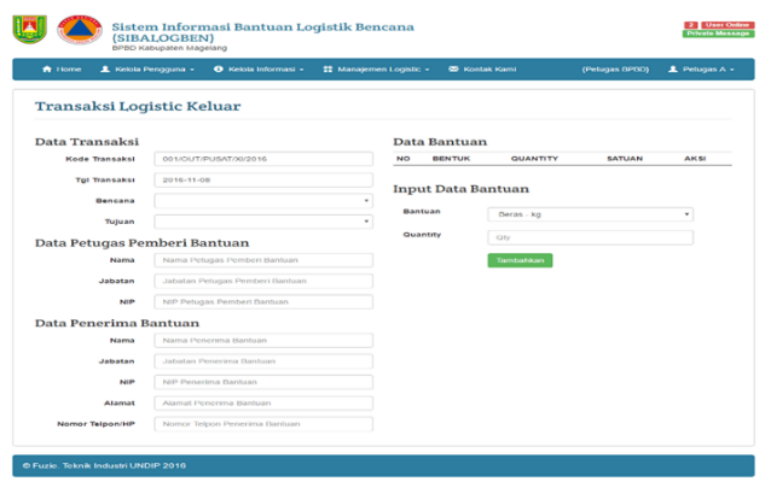

Gambar 9. Form logistik keluar

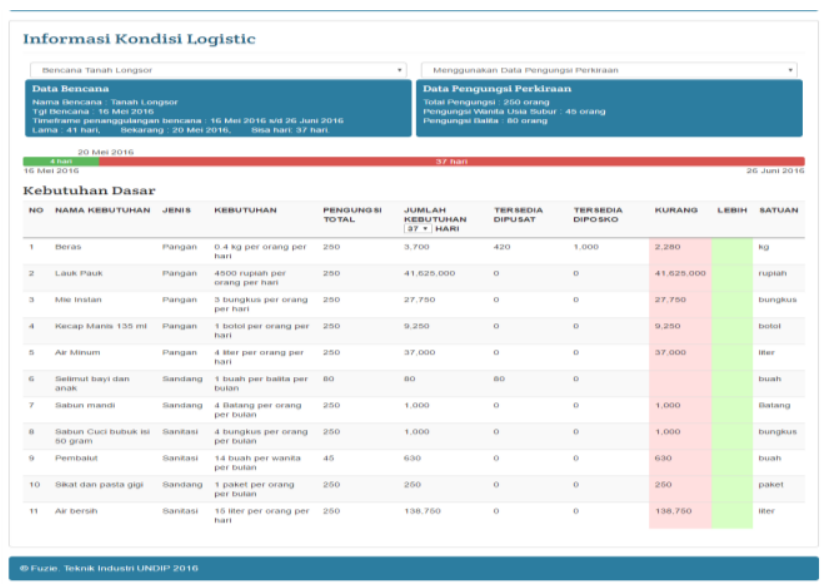

Gambar 10. Kondisi logistik keseluruhan

4. Halaman daftar standar kebutuhan logistik

Gambar 7. merupakan gambar dari halaman daftar standar kebutuhan dasar logistik bencana yang telah diatur oleh petugas posko induk BPBD berdasarkan PERKA BNPB nomor 18 tahun 2009 dan nomor 10 tahun 2012.

5. Halaman formulir transaksi logistik masuk
Gambar 8. memperlihatkan halaman transaksi logistik masuk yang digunakan untuk menambahkan transaksi logistik masuk untuk mencatatkan bantuan yang diterima dari donatur.

6. Halaman formulir transaksi logistik keluar

Gambar 9. merupakan halaman transaksi logistik keluar yang digunakan untuk menambahkan catatan bantuan yang didistribusikan kepada pengungsi. 
Tabel 1. Uji Blackbox

\begin{tabular}{|c|c|c|c|}
\hline No & Kelas Uji & Butir Uji & Hasil \\
\hline 1 & Login dan Logout & Memasukan nama pengguna dan kata sandi & Sesuai \\
\hline \multirow{2}{*}{2} & \multirow{2}{*}{ Kelola Profil Instansi oleh Petugas Posko BPBD } & Membuat Profil Instansi & Sesuai \\
\hline & & Merubah Profil Instansi & Sesuai \\
\hline \multirow{5}{*}{3} & \multirow{5}{*}{$\begin{array}{l}\text { Kelola Bencana dan Posko oleh Petugas Posko } \\
\text { BPBD }\end{array}$} & Menambah data bencana & Sesuai \\
\hline & & Menyunting data bencana & Sesuai \\
\hline & & Melihat data petugas posko desa & Sesuai \\
\hline & & Melihat data pengungsi di posko desa & Sesuai \\
\hline & & Melihat kondisi logistik posko desa & Sesuai \\
\hline \multirow{3}{*}{4} & \multirow{3}{*}{ Kelola Kebutuhan Dasar oleh Petugas Posko BPBD } & Melihat data kebutuhan dasar & Sesuai \\
\hline & & Menambahkan data kebutuhan dasar & Sesuai \\
\hline & & Menyunting data kebutuhan dasar & Sesuai \\
\hline \multirow{3}{*}{5} & \multirow{3}{*}{ Kelola Transaksi Logistik Masuk di Posko BPBD } & Mencatatkan transaksi bantuan logistik yang diterima & Sesuai \\
\hline & & Menyunting transaksi bantuan logistik yang diterima & Sesuai \\
\hline & & Mencetak berita acara bantuan logistik masuk & Sesuai \\
\hline \multirow{3}{*}{6} & \multirow{3}{*}{$\begin{array}{l}\text { Kelola Transaksi Logistik yang Disalurkan oleh } \\
\text { Posko BPBD }\end{array}$} & $\begin{array}{l}\text { Mencatatkan transaksi bantuan logistik yang disalurkan } \\
\text { (keluar) }\end{array}$ & Sesuai \\
\hline & & Menyunting transaksi bantuan logistik yang disalurkan (keluar) & Sesuai \\
\hline & & Mencetak berita acara bantuan logistik yang dialurkan (keluar) & Sesuai \\
\hline \multirow{2}{*}{7} & \multirow{2}{*}{ Melihat Kondisi Logistik di Posko BPBD } & $\begin{array}{l}\text { Melihat Kondisi Logistik di Posko BPBD menggunakan data } \\
\text { pengungsi perkiraan }\end{array}$ & Sesuai \\
\hline & & $\begin{array}{l}\text { Melihat Kondisi Logistik di Posko BPBD menggunakan data } \\
\text { pengungsi sebenarnya }\end{array}$ & Sesuai \\
\hline \multirow{2}{*}{8} & \multirow{2}{*}{ Kelola Laporan oleh Petugas Posko BPBD } & Memilih Jenis Laporan \& nama Bencana & Sesuai \\
\hline & & Mencetak Laporan & Sesuai \\
\hline \multirow{2}{*}{9} & \multirow{2}{*}{ Kelola Kontak Kami } & Membaca pesan masuk pada halaman kontak kami & Sesuai \\
\hline & & membalas pesan dari halaman kontak kami & Sesuai \\
\hline \multirow{2}{*}{10} & \multirow{2}{*}{ Kelola Posko Desa oleh Petugas Posko Desa } & Mengisi formulir data posko desa & Sesuai \\
\hline & & Menyunting data posko desa & Sesuai \\
\hline \multirow{3}{*}{11} & \multirow{3}{*}{ Kelola Pengungsi oleh Petugas Posko Desa } & Menambahkan nama kepala keluarga pengungsi & Sesuai \\
\hline & & Menmbahkan data keluarga dari kepala keluarga pengungsi & Sesuai \\
\hline & & Menyjnting nama kepala keluarga pengungsi & Sesuai \\
\hline \multirow{2}{*}{12} & \multirow{2}{*}{ Melihat Kondisi Logistik di Posko Desa } & $\begin{array}{l}\text { Melihat Kondisi Logistik di Posko Desa menggunakan data } \\
\text { pengungsi perkiraan }\end{array}$ & Sesuai \\
\hline & & $\begin{array}{l}\text { Melihat Kondisi Logistik di Posko Desa menggunakan data } \\
\text { pengungsi sebenarnya }\end{array}$ & Sesuai \\
\hline \multirow{3}{*}{13} & & Mencatatkan transaksi bantuan logistik yang diterima & Sesuai \\
\hline & Kelola Transaksi Logistik Masuk di Posko Desa & Menyunting transaksi bantuan logistik yang diterima & Sesuai \\
\hline & & Mencetak berita acara bantuan logistik masuk & Sesuai \\
\hline & Kelola Transaksi Logistik yang Disalurkan oleh & $\begin{array}{l}\text { Mencatatkan transaksi bantuan logistik yang disalurkan } \\
\text { (keluar) }\end{array}$ & Sesuai \\
\hline 14 & Posko Desa & Menyunting transaksi bantuan logistik yang disalurkan (keluar) & Sesuai \\
\hline & & Mencetak berita acara bantuan logistik yang dialurkan (keluar) & Sesuai \\
\hline & & Memilih jenis laporan & Sesuai \\
\hline 15 & Kelola Laporan oleh Petugas Posko Desa & Mencetak Laporan & Sesuai \\
\hline 16 & Halaman Posko oleh Penouniung Woh & Menampilkan daftar posko desa berdasarkan bencana & Sesuai \\
\hline 10 & Halaman Posko olen Pengunjung web & Menampilkan detail posko desa & Sesuai \\
\hline & & $\begin{array}{l}\text { Menampilkan statistik jumlah pengungsi berdasrkan rentang } \\
\text { usia per bencana }\end{array}$ & Sesuai \\
\hline 17 & Halaman Posko oleh Pengunjung Web & $\begin{array}{l}\text { Menampilkan Detail statistik jumlah pengungsi berdasrkan } \\
\text { rentang usia per bencana }\end{array}$ & Sesuai \\
\hline & & Menampilkan kondisi logistik keseluruhan & Sesuai \\
\hline 18 & Halaman Kebutuhan Dasar & Menampilkan kondisi logistik perdesa & Sesuai \\
\hline 19 & Halaman Donatur & Menampilkan data daftar nama donatur & Sesuai \\
\hline & & Memasukkan nama pengungsi yang dicarai & Sesuai \\
\hline 20 & Halaman Cari Pengungsi & Menampilkan hasil pencarian pengungsi & Sesuai \\
\hline
\end{tabular}


7. Halaman kondisi logistik Keseluruhan

Gambar 10. Menunjukkan kondisi logistik secara keseluruhan.

\section{Pengujian}

Setelah sistem informasi telah terbangun, maka langkah selanjutnya adalah melakukan pengujian sistem. Pada pengujian sistem, suatu sistem informasi dijalankan dengan data yang telah dipilih untuk mencari kesalahan jika ada (Pressman \& Maxim, 2015). Untuk melakukan pengujian sistem informasi bantuan logistik bencana (SIBALOGBEN) menggunakan metode unit testing dengan menggunakan black box testing.

Pengujian menggunakan black box testing dilakukan dengan cara menjalankan fungsi masing-masing modul, kemudian diamati apakah fungsi yang dijalankan pada masing-masing modul sudah berjalan sesuai dengan sistem yang telah dirancang. Tabel 1. menunjukkan hasil pengujian dengan menggunakan black box testing.

Berdasarkan Tabel 1., dapat dilihat bahwa fungsifungsi yang terdapat pada SIBALOGBEN telah berjalan dengan baik dan sesuai rancangan yang telah dibuat. Fungsi pada sistem telah berhasil digunakan serta tidak terjadi kesalahan, jika terdapat kesalahan atau peringatan dari sistem, hal ini disebabkan oleh pengguna yang tidak memberikan input dengan benar.

\section{KESIMPULAN}

Proses manajemen bantuan logistik yang diterapkan oleh BPBD kabupaten Magelang terdiri dari fase perencanaan dan fase penerimaan atau pengadaan bantuan logistik bencana. Dalam fase perencanaan dilakukan perhitungan jumlah pengungsi yang membutuhkan bantuan logistik, jenis dan jumlah kebutuhan yang dibutuhkan, dan perencanaan pendistribusian bantuan. Fase kedua adalah fase penerimaan atau pengadaan, di dalam fase ini penggolongan bantuan yang diterima dari donatur dan pemerintah, dan dilakukan pencatatan untuk semua bantuan yang diperoleh dan tempat tujuan pendistribusian. Pada penelitian ini dibangun sistem informasi yang dapat mempercepat perhitungan jenis dan jumlah komoditi yang dibutuhkan. Selain itu, dengan adanya sistem informasi ini, pencatatan penerimaan bantuan dapat disinkronisasi sehingga seluruh komoditi yang telah tersedia di masing-masing lokasi dapat diketahui. Output sistem informasi ini dapat dipublikasikan secara luas kepada masyarakat, sehingga respon penanggulangan terhadap bencana dapat dilakukan dengan cepat, dan masyarakat dapat mengetahui komoditi yang masih diperlukan oleh korban bencana.

Pada penelitian berikutnya akan dilakukan pengembangan sistem informasi bantuan logistik bencana pada berbagai jenis bencana dan berbagai wilayah di Indonesia.

\section{DAFTAR PUSTAKA}

'--- ' (2007). Undang-Undang Nomor 24 Tahun 2007.

Peraturan pemerintah no 22 tahun 2008 tentang pendanaan dan pengelolaan bencana

Peraturan kepala badan nasional penanggulangan bencana (PERKA BNPB) nomor 18 tahun 2009 tentang pedoman standarisasi logistik penanggulangan bencana

Peraturan kepala badan nasional penanggulangan bencana (PERKA BNPB) nomor 10 tahun 20012 tentang pengelolaan bantuan logistik pada saaat keadaan darurat

Whitten L., and Lonnie D. Bentley. 2007. System Analysis and design Methods $7^{\text {th }}$ Edition. McGrawHill Higher Education

O’Brien, G., P. O'Keefe, Z. Gadema, J. Swords, 2010. "Approaching disaster management through social learning", Disaster Prevention and Management, 19 498-508

Cozzolino, A. 2012. Humanitarian Logistics: Crosssector Cooperation in Disaster Relief Management, Springer, NewYork

Pressman, R.S., and Maxim Bruce R., 2015, Software Engineering: A Practitioner's Approach Eight Edition, McGraw-Hill, New York

Azlia, W., Pujawan, I Nyoman, dan Kurniati, Nani. 2010. "Penentuan Lokasi Fasilitas Gudang Kesiapsiagaan Untuk Bencana Alam Dengan Mempertimbangkan Kerentanan Wilayah". Prosiding Seminar Nasional Manajemen Teknologi XII.A21-2 - A21-10

Nugraha, Ikhsanuddin S dan Halim,Abdul Hakim. 2012. "Model Penetuan Lokasi Barak Pengungsian dan Gudang Pemasok Dalam Penanggulangan Bencana Alam". Prosiding seminar sistem produksi X.No.2,48-56

Oktarina, Rienna. 2009. "Konseptual Perancangan Sistem Informasi Manajemen Logistik Dalam Penanggulangan Bencana (SIMLOG-PB) Berbasis GIS di Indonesia." Seminar Nasional Aplikasi Teknologi Informatika. B16-B22

Oktarina, Rienna. 2008. Pemetaan Sistem Informasi Manajemen Logistik dan Penanggulangan Bencana di Indonesia. Seminar Nasional Aplikasi Teknik Informasi (SNATI), Yogyakarta 21 Juni 2008 